\title{
Performance Evaluation of Sorghum (Sorghum bicolor (L.) Moench) Varieties in the Lowlands Area of Wag Lasta, North Eastern Ethiopia
}

\author{
Abebe Assefa $^{1 *} \quad$ Aemiro Bezabih $^{2} \quad$ Getaway Germany $^{1} \quad$ Tesfaye Alemayehu $^{1}$ \\ 1.Sekota Agricultural Research Center, P.O. Box, 62, Sekota, Ethiopia \\ 2.Debre Birhan Agricultural Research Center, P.O. Box, 112, Debre Birhan, Ethiopia
}

\begin{abstract}
Eight released sorghum varieties were evaluated in four environments in the Wag-himra and Lasta in main production season for two years (2016 and 2017). The objective of the trial was to identify high yielder sorghum varieties that possesses farmers preferred traits for production in both testing sites. The trial was conducted using a randomized complete block design with three replications. The GGE statistical model was used for analyzing genotype by environment interaction GEI and to assess the stability of sorghum variety for grain yield. A combined analysis of variance for grain yield and yield related traits showed that the main effects of both genotypes and environments, and the interaction effect, were highly significant $(\mathrm{P} \leq 0.001)$. The mean values of grain yield ranged from $1300 \mathrm{~kg}$ ha-1 (Dagim) to $2800 \mathrm{~kg}$ ha-1 (Melkam) with the overall mean values of $2100 \mathrm{~kg}$ ha-1. Based on the GGE biplot analysis, high yielding variety Melkam (2800 kg ha-1) showed better performance stability across the test environments. In addition, the result of participatory variety selection (PVS) revealed that Melkam ranked first and second preferred sorghum variety in Lasta and Waghimira agro-ecologies, respectively. We recommend, therefore, Melkam for production in both agro-ecologies and similar areas of the country. This variety will play a role in enhancing farmers' income through improved grain yield, especially in the dry lowlands areas of Waghimra and Lasta.
\end{abstract}

Keywords: Farmer preferred trait, GGE, PVS, stability, yield

DOI: $10.7176 / \mathrm{JBAH} / 10-7-05$

Publication date: April $30^{\text {th }} 2020$

\section{Introduction}

Sorghum (Sorghum bicolor( L.)Moench.) is an important cereal, particularly in the world's semi-arid tropics. It is a major food crop in sub-Saharan Africa and South Asia and is the staple food for the most food insecure people in the world (Bibi et al., 2010). It is the world's fifth most important cereal, after wheat, rice, maize and barley (FAO, 2010). More than 105 countries in Africa, Asia, Oceania and the Americas grow sorghum on 40 million hectares (Kumar et al., 2011), and 60\% of this land is in Africa (FAO, 2008), where it continues to play an important food security role (Mutegi et al., 2011). Ethiopia is the primary center of origin and diversity for sorghum (Doggett 1988; Firew, 2006). It is widely distributed throughout Ethiopia and it is the most important cereal in the lowland areas because of its drought tolerance (Kebede, 1991).

Sorghum is the most importat crop in moisture deficit areas of eastern Amhara(CSA, 2017).The crop is used in various ways. The grain is used as whole flour mostly for processing injera.The flour is also used for the preparation of kita (non-fermented unraised bread or unleavened bread) and local alcoholic drinks. Besides the grain, sorghum straw is an important feed for livestock. However, the productivity of sorghum is low (15 kg/ha) in Wag-himra (CSA, 2017). This low productivity is mainly due to drought, poor soil fertility and lower yielding varieties.

Because of the significance of sorghum for food security in the drought prone areas, the development of early maturing varieties with reasonable yields have been a main focus of breeding programs in Ethiopia as well as in Sub-Saharan Africa (McGuire, 2005; Firew, 2006, Asfaw, 2007). For the past five decades, many early maturing sorghum varieties have been developed and released for lowland parts of Ethiopia by the Federal and Regional Agriculture Research Centers as well as Universities. Therefore, the objective of this study was to select high yielding and farmers preferred sorghum varietyes for the low land area of wag lasta.

\section{Material and Methods}

\subsection{Plant material, experimental site and experimental design}

Eight nationally and regionaly released sorghum varieties and a local check were evaluated during 2016 and 2017 the main cropping seasons at Aybera and Lalibela sites. Both testing sites represent the low land sorghum growing environments of the Waghimra and Lasta. Description of the experimental location and the sorghum varieties are presented in Table 1 and Table 2.

The experiment was laid out on Randomized Completely Block Design (RCBD) with three replications. Each variety was planted on a plot size of $18.75 \mathrm{~m} 2$ ( $5 \mathrm{~m}$ length by $3.75 \mathrm{~m}$ width), with an intra- and inter-row spacing 
of 0.15 and $0.75 \mathrm{~cm}$, respectively. Nitrogen and Phosphorous fertilizers were applied in the form of Urea and NPS at the rate of $41 \mathrm{kgha}^{-1} \mathrm{~N}$ and $46 \mathrm{kgha}^{-1} \mathrm{P} 2 \mathrm{O} 5$, respectively. All the recommended $\mathrm{P} 2 \mathrm{O} 5$ and half of nitrogen were applied during planting whereas the remaining half of nitrogen was top-dressed at knee-height stage.

Table 1. Description of the experimental area used for evaluation of the sorghum varieties

\begin{tabular}{lcc}
\hline & \multicolumn{2}{c}{ Testing site } \\
\cline { 2 - 3 } Variable & Aybra $2016-2017$ & Lalibela $2016-2017$ \\
\hline Longitude & $12^{0} 43^{\prime}, 38^{\prime} \mathrm{N}$ & $11^{0} 58,18, \mathrm{~N}$ \\
Latitude & $79^{0} 01,08, \mathrm{E}$ & $38^{0} 58,54, \mathrm{E}$ \\
Altitude meter above sea level & 1915 & 1963 \\
Average annual rainfall mm & 492 & 769 \\
Average maximum temperature $\mathrm{C}^{0}$ & 26.9 & 24.7 \\
Average minimum temperature $\mathrm{C}^{0}$ & 15.4 & 13.6 \\
Soil type & Vertisol & Vertisol \\
\hline
\end{tabular}

Table 2. Description the 9 sorghum varieties

\begin{tabular}{llccc}
\hline No & Variety Name & Pedigree & Mantainer & Year of release \\
\hline 1 & Melkam & WSV-387 & MARC & 2009 \\
2 & Dekeba & ICSR 24004 & MARC & 2012 \\
3 & Dagem & 97 MW6130 & MARC & 2011 \\
4 & Geremew & $87 B K-4122$ & MARC & 2007 \\
5 & Chare & PGRC/E\#222880 & DBARC & 2011 \\
6 & Mesay & Meko x Gobye & SARC & 2011 \\
7 & Gambella & Gambella 1107 & MARC & 1976 \\
8 & Meko-1 & M-36121 & MARC & 1997 \\
9 & Local check & & & \\
\hline
\end{tabular}

Abbreviation; Melkassa Agricultural Research Center (MARC), Sirinka Agricutural Rearch center (SARC), D/Birhan Agricutural Reseach centr(DBARC)

\subsection{Data collection and statistical analysis}

Phenotypic data on quantitative traits were collected on plant and plot basis. Days to $50 \%$ heading (DH), and days to $90 \%$ maturity (DM) were measured on plots basis. Plant height $(\mathrm{PH}$, in $\mathrm{cm})$, head length $(\mathrm{HL}$, in $\mathrm{cm})$, and head weight $(\mathrm{HW}$, in $\mathrm{cm}$ ) were measured on five randomly selected plants per plot. Grain yield (GY; grams of grain produced per plot, which is later converted in $\mathrm{kg} / \mathrm{ha}$ ) and thousand seed weight( TSW) were measured on the plots basis as per IBGR and ICRISAT (1993).

Farmers' participatory varietal selection was conducted to select sorghum variety that possesses farmers preferred traits and farmers make selection on the four babay trials. The baby trials was a single replication and the farmers land which the baby is plannting is considering as a single replication. A total of 16 farmers $($ Men $=$ 12 , Women $=4$ ) was participated in the participatory selection of sorghum variety at physiological maturity stage of the crop. Farmers listed the traits they used to evaluate a sorghum variety, which were ranked by importance. Each sorghum variety was evaluated by farmers based on the overall performance of each variety related to the three farmer traits including earliness, head length and seed color.

Analysis of variance was computed using SAS software v9.0 (SAS Institute, Cary, USA). Combined data analyses were computed after testing the homogeneity of error variances using Bartlett's test (Gomez and Gomez, 1984). Mean separation was carried out using least significant difference (LSD) at 5 percent level of significance. Genotype and genotype by environment interaction biplot analysis (Yan 2002) and correlation analysis were computed using GENSTAT software program $18^{\text {th }}$ edition.

\section{Result and Discussion}

\subsection{Grain yield and yield related traits}

A combined analysis of variance for seven traits of the eight sorghum varieties and one local check tested across four environments is presented in Table 2. The analysis of variance for grain yield and yield related traits showed that the main effects of both genotypes and environments, and the interaction effect, were highly significant $(\mathrm{P} \leq$ 0.001). This indicates that genotype, environment and their interaction are important in governing the expression of these traits. The significant genotype by environment interaction resulted either from differential responses of the variety to the test growing environments for these traits or changes in the relative ranking of genotypes. Asfaw (2008) in sorghum reported a similar result that showed a significant difference of genotypes, environment and genotype by environment effect for grain yield in dry hot lowlands of Ethiopia. 
Table 2. Combined analysis of variance from nigh sorghum varieties for seven traits

\begin{tabular}{lccccc}
\hline Traits & Env $(3)^{\dagger}$ & Var $(8)$ & Env x Var $(24)$ & Pooled error (64) & R-Square \\
\hline DH & $638.87^{* *}$ & $1020.10^{* *}$ & $114.34^{* *}$ & 22.54 & 0.90 \\
DM & $2552.12^{* *}$ & $431.18^{* *}$ & $211.94^{* *}$ & 84.00 & 0.76 \\
PH & $7375.84^{* *}$ & $8566.08^{* *}$ & $270.87^{* *}$ & 178.05 & 0.90 \\
HL & $134.94^{* *}$ & $185.24^{* *}$ & $26.22^{* *}$ & 7.07 & 0.85 \\
HW & $442208.46^{* *}$ & $14973.84^{* *}$ & $5617.37^{* *}$ & 966.41 & 0.96 \\
TSW & $75.07^{* *}$ & $317.75^{* *}$ & $16.27^{\text {ns }}$ & 9.75 & 0.84 \\
GY & $3996.15^{* *}$ & $234.26^{* *}$ & $38.52^{* *}$ & 12.98 & 0.95 \\
\hline
\end{tabular}

$\dagger \quad$ Numbers in parenthesis represent degrees of freedom, ns, *, **, = Non Significant, significant at $\mathrm{P} \leq 0.05$ and significant at $\mathrm{P} \leq 0.01$ respectively, Env $=$ Environments, $\mathrm{Var}=$ Varieties, $\mathrm{DH}=$ Days to heading, $\mathrm{DM}=\mathrm{Days}$ to maturity, $\mathrm{PH}=$ plant height $(\mathrm{cm}), \mathrm{HL}=$ Head length $(\mathrm{cm}), \mathrm{HW}=\mathrm{Head}$ weight $(\mathrm{gm}), \mathrm{TKW}=1000$ kernel weight (gm), $\mathrm{GY}=$ Grain yield $(\mathrm{kg} / \mathrm{ha})$

The number of days to maturity combined over four environments ranged from 117 days (Meko and Melkam) to 132 days (Geremew) with an average day of 123. The mean values of head length ranged from $17 \mathrm{~cm}$ (Chare) to $28 \mathrm{~cm}$ (Dagim), with a mean of $22 \mathrm{~cm}$. The mean value of thousand kernel weight ranged from $18 \mathrm{gm}(\mathrm{Geremew})$ to $31 \mathrm{gm}$ (Meko and Mesay) with the average values of $26 \mathrm{gm}$. The mean values of grain yield ranged from 1300 $\mathrm{kg}$ ha-1 (Dagim) to $2800 \mathrm{~kg}$ ha-1 (Melkam) with the average values of $2100 \mathrm{~kg}$ ha- 1 . The result shows that there is a reduction in grain yield as compared to the national productivity of sorghum in Ethiopia, which is $25 \mathrm{~kg}$ ha1(CSA, 2017), indicating the effect of moisture deficit on yield of sorghum at Wag-himra and Lasta is very important. In general, these areas are characterized by a highly unreliable rainfall with a limited amount and erratic distribution, which causes significant yield reduction and sometime total failure of sorghum in the areas (SDARC Annual Progress Research Reports for the period 2006/07 to 2014/15). Previous reports indicated that the major cause of grain yield reduction during moisture deficit is mainly associated with a reduction in grain size (Blum $e t$ al., 1989, Yadav, et al., 2003 in sorghum; Ozurk and Aydin, 2004 in wheat).

Table 8. Mean values of grain yield and yield related traits of sorghum varieties tested at four environments

\begin{tabular}{clccccccc}
\hline No & Varieties & DH $^{@}$ & DM & PH & HL & HW & TSW & GY \\
\hline 1 & Melkam & 71 & 117 & 128 & 27 & 199 & 30 & 2800 \\
2 & Dekeba & 83 & 124 & 109 & 21 & 186 & 23 & 2100 \\
3 & Dagim & 95 & 130 & 118 & 28 & 98 & 19 & 1300 \\
4 & Geremew & 91 & 132 & 119 & 25 & 150 & 18 & 1500 \\
5 & Chare & 76 & 120 & 143 & 17 & 143 & 24 & 2200 \\
6 & Mesay & 70 & 120 & 161 & 24 & 155 & 31 & 2400 \\
7 & Gambella & 79 & 118 & 139 & 19 & 171 & 24 & 2000 \\
8 & Meko & 69 & 117 & 146 & 21 & 141 & 31 & 2200 \\
9 & Local & 83 & 130 & 196 & 18 & 216 & 30 & 2100 \\
\hline & Mean & 80 & 123 & 140 & 22 & 162 & 26 & 17 \\
& C.V(\%) & 6 & 7 & 10 & 12 & 19 & 12 & 2.94 \\
\hline
\end{tabular}

@ refer to $\mathrm{DH}=$ Days to heading, $\mathrm{DM}=$ Days to maturity, $\mathrm{PH}=$ plant height $(\mathrm{cm}), \mathrm{HL}=$ Head length $(\mathrm{cm}), \mathrm{HW}=$ Head weight $(\mathrm{gm}), \mathrm{TKW}=1000$ kernel weight $(\mathrm{gm}), \mathrm{GY}=$ Grain yield $(\mathrm{kg} / \mathrm{ha})$

The correlation among traits is presented in Figure 1. Grain yield had a positive and significant association with thousand kernel weight and plant height. This result agrees with previous studies by (Khizzah and Miller 1992; Kadam et al. 2002 and Aemiro et al., 2017) in sorghum who reported a positive correlation between grain yield with plant height and thousand kernel weight. Significant association was observed in the following pairs of traits; days to heading with days to maturity and thousand kernel weight, plant height with thousand kernel weight and head length ; head weight with head length and thousand kernel weight. The presence of association is the indication that those traits are conditioned by the same set of gene, is it in the positive or negative direction (Falconer, 1989). Therefore, selection for one trait can indirectly introduce changes in the other trait in positive or negative direction due to either genetic linkage or the existence of a pleiotropic gene effect or both (Falconer, 1989). 


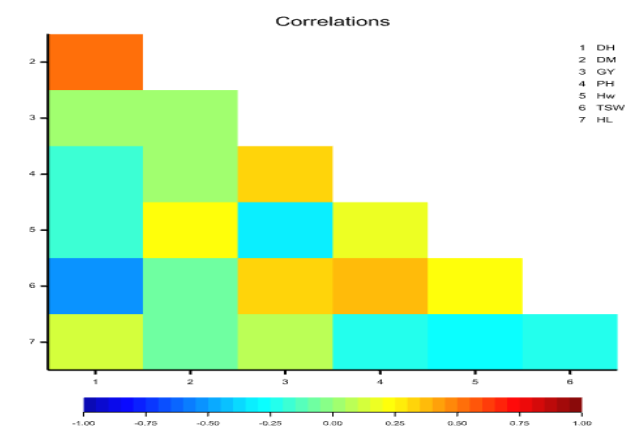

Figure 1. Correlations among yield and yield related traits

\subsection{Participatory variety selection (PVS)}

Results of PVS showed that Local check was the least preferred variety in both testing sites (Data not shown), this indicates that the demand for improved variety of sorghum in the areas. At Lalibela site variety Melkam ranked first, followed by Dekeba and Geremew whereas, at Aybra site the highest rank value was recorded for variety Meko followed by Melkam and Dekeba. The reasons of the preference for these varieties were related to earliness, head length and seed color. Similar to farmers, researchers may use sorghum head related traits to predict the yield potential of a specific type of sorghum variety (Subba Redy and Rao, 1971; Blum et al., 1989; Haussmann et al., 1999; Aemiro et al., 2017). Several authors reported the importance of farmers involvement (PVS) in variety selection in order to use their indigenous knowledge for variety use related traits and share their traits preference (Gyawali et al., 2010 in rice; Demissew et al., 2013, in maize; Nkongolo et al., 2008, in sorghum; Mancini et al., 2017 in durum wheat). Joshi et al., (1995) reported that in addition to grain yield, farmers also consider other parameters like growing period, plant height, thresh ability, milling recovery, taste and other characters of rice.

\subsection{Genotype and genotype by environment interactions biplot analysis for grain yield}

GGE biplot based on PC1 and PC2 is indicated in Figure 2. Genotypes located at the vertices of the polygon performed either the best or the poorest in one or more locations since they had the longest distance from the origin of biplot (Yan and Kang, 2003). Accordingly, the vertex genotypes in this study were V1, V6, V4, and V3 which were the best or the poorest varieties in some or all of the environments because they were farthest from the origin of the biplot.

Polygon view of a biplot is most relevant to the investigation of the mega-environments and visualization of the which-won-where pattern of multi environment trial data (Yan et al., 2001) and it is important for studying the possible existence of different mega-environments in a region (Gauch and Zobel, 1997). V1 was high yielding variety at the first mega environment which contains the test environments; EV1, EV2 and EV3; the second mega environment contains Ev3 with V6 as the best yielder. The vertex variety V3 and V4 were not the top yielding genotypes in any environment. They were the poorly performing varieties with average grain yield below the grand mean. Genotype that fall in the central (concentric) circle is considered stable genotype (Yan, 2002). Genotypefocused comparison of genotypes revealed that genotype V1 fell in the central circle, was the ideal genotype in terms of higher yielding potential and stability, compared to the rest of genotypes evaluated in this study (Figure 3.). The GGE biplot analysis depicted V1 as stable variety. 


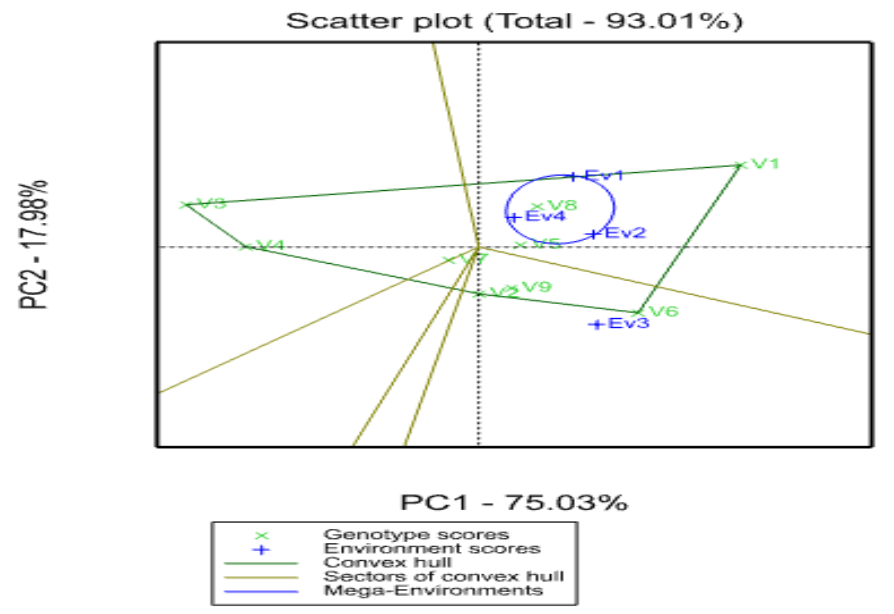

Ev1= Aybra 2008/2009; Ev2= Aybra 2009/2010; Ev3= Lalibela 2008/2009; Ev4= Lalibela 2009/2010; V1=Melkam; V2=Dekeba; V3=Dagim ; V4=Geremew ; V5=Chare ; V6= Mesay; V7=Gambella; V8=Meko; V9=Local .

Figiure 3. Polygon view of the GGE biplot show the "which-won-where" for 9 sorghum varieties over 4 test environments.

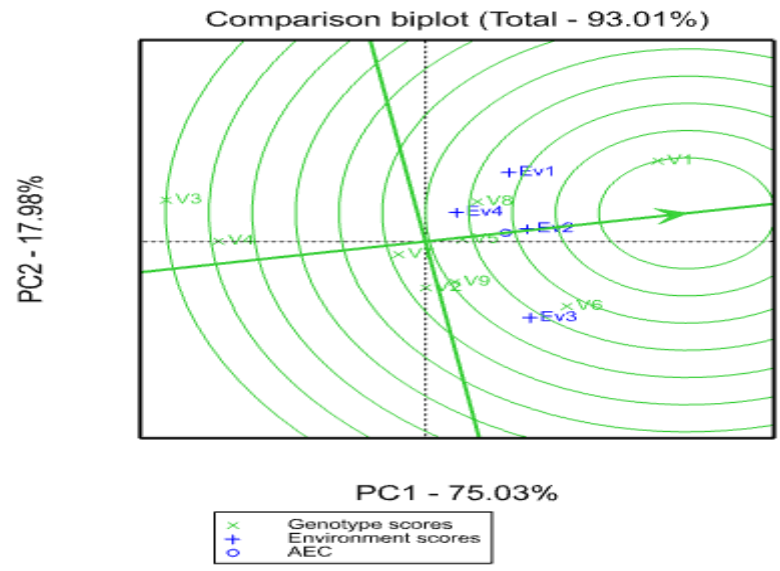

Figure 4. GGE-biplot based on genotype-focused scaling for comparison the genotypes with the ideal genotype.

\section{Conclusions and recommendations}

Sorghum is one of the most dominant cereal crop both socially and agriculturally especially in the dry lowlands areas of Wag-himra and Lasta. Based on the GGE biplot analysis, high yielding variety Melkam (2800 kg ha-1) showed better performance stability across the test environments. Moreover, results of participatory variety selection (PVS) revealed that Melkam ranked first and second preferred sorghum variety in Lasta and Waghimira testing sites, respectively. For this reason, V1 (Melkam) is recommended for production in both testing sites and similar agro-ecologies of the country, for its yield, stability and seed color. This variety will play a role in enhancing farmers' income through improved grain yield, especially in the dry lowlands areas of Wag-himra and Lasta.

\section{Acknowledgements}

We acknowledge the Amhara Agricultural Research Institute (ARARI) for financial support to conduct this study.

\section{Reference}

Aemiro Bezabih, Firew Mekbib, Setegn Gebeyhu and Mulualem T. Kassa (2017). Character association in sorghum stay-green QTL introgression lines to post flowering drought resistance in North East Ethiopia. In: 
Alemayehu Assefa, Baye Berihun and Ermiae Abate (eds.). Proceeding of the 8th Annual Regional Conference on Completed Crop Research Activities,13- 20 February 2014, Amhara Regional Agricultural Research Institute, Bahir Dar, Ethiopia.

Asfaw Adugna, (2007) Assessment of yield stability in sorghum. Ethiopia. African Crop Science Journal, 15(2): 83-92.

Asfaw Adugan (2008).Assessment of yield stability in sorghum using univariate and multivariate statistical approaches. Hereditas, 145: 28-37.

Bibi A, Sadaqat H.A., Akram H.M, Mohammed M.I. (2010) Physiological markers for screening sorghum (Sorghum bicolor) germplasm under stress condition. International J Agric Biol, 12:451-455

Blum, A. Mayer, J. and Golan, G. (1989) Agronomic and physiological assessments of genotypic variation for drought resistance in sorghum. Aust. J. Agric. Res., 40: 49-61

Central Statistical Agency, CSA. (2017). Report on Area and Production of Crops. Statistical Bulletin 584, Volume I, Addis Ababa.

Demissew Abakemal, Shimelis Hussein, John Derera and Mark Laing (2013). Farmers' Perceptions of Maize Production Systems and Breeding Priorities, and Their Implications for the Adoption of New Varieties in Selected Areas of the Highland Agro-Ecology of Ethiopia , Journal of Agricultural Science; 511; 2013

Doggett, H., (1988). Sorghum. New York, NY: John Wiley.

Ezeaku, I.E. and Mohammed, S.G., (2006) .Character association and path analysis in grain sorghum. African Journal of Biotechnology. 5 (14): 1337-1340.

Falconer, D.S. (1989). Introduction to quantitative genetics. Longman Scientific and Technical. New York.

FAO. 2010. FAOSTAT. Available at http://www.faostat.fao.org (accessed on December 23, 2012).

Fernandez, G.C. (1992). Effective selection criteria for assessing stress tolerance. In: Kou, C.G. (ed.).Proceedings of International Symposium on Adaptation of Vegetables and Other Food Crops in Temperature and Water Stress, Publication, Tainan, Taiwan.

Firew Mekbib, (2006). Farmer and formal breeding of sorghum (Sorghum bicolor (L.) Moench) and the implications for integrated plant breeding. Euphytica, 152: 163-176.

Gomez A.K. and Gomez A.A. 1984. Statistical Procedures for Agricultural Research. 2nd edition. John Wiley and Sons. New York.

Gul, I. Saruhan, V. and Basbag, M. (2005). Determination of yield and yield components and relationship among the components of grain sorghum cultivars grown as main crop. AsianJournal of Plant Sciences, 4: 613-618.

Gauch, H.G. and Zobel, R.W. (1997). Identifying mega-environments and targeting genotypes. Crop Science, 37 : 311-326

Gyawali, S. Sthapit, B.R. Bhandari, B. Bajaracharya, J. Shrestha, P.K. Upadhyay, M.P. Jarvis, D.I. (2010). Participatory crop improvement and formal release of Jethobudho rice landrace in Nepal. Euphytica 24: 3032

Haussmann, B.I.G. Obilana, A.B. Blum, A. Ayiecho, P.O. Schipprack, W. and Geiger, H.H. (1999). Quantitative genetic parameters of sorghum (Sorghum bicolor (L.) Moench) grown in semi-arid areas of Kenya. Euphytica. 105: 109-118.

IBPGR and ICRISAT (1993). Descriptors for sorghum [Sorghum bicolor (L.)Moench]. International Board Plant Genetentic Resources, Rome, Italy. ICRISAT, Patancheru, India.

Joshi, K.D. Rana, R.B. Subedi, M. Kadayat, K.B. and Sthapit, B.R. (1995). Effectiveness of participatory testing and dissemination programme: a case study of Chaite Rice in the western hills of Nepal. LARC working paper No. 95/49. Pokhara, Nepal: Lumble Agricultural Research Centre.

Kadam, G.N. Gadakh, S.R. and Awari, V.R.. (2002). Physiological analysis of rabi sorghum genotypes for shallow soil. Journal of Maharashtra Agricultural Universities, 27 (3): 274276.

Kebede, D. Subudhi, P.K. Rosenow, D.T. Nguyen, H.T. (2001). Quantitative Trait Loci influencing drought tolerance in grain sorghum.Theoretical and Applied Genetics, 103: 266-276.

Kebede Y. (1991). The role of Ethiopian sorghum germplasm resources in the national breeding programme. In: Plant Genetic Resources of Ethiopia (eds JM Engels, JG Hawkes and M Worede), Cambridge University Press, Cambridge, p. 315-322.

Khizzah, B.W. and Miller, F. R. (1992). Correlations between sorghum components of drought resistance and various agronomic characters at four locations. Sorghum Newsletter, 33: 54.

Kumar, A.A. Reddy, B.V.S. Sharma, H.C. Hash, C.T. Rao, P.S. Ramaia, B. Reddy, P.S. (2011) Recent advances in sorghum genetic enhancement research at ICRISAT. Am J Plant Sci 2:589-600

Mancini, C. Yosef Kidane, Dejene Mengistu, Melfa and Workaye Farmer Community, Pè M. E. Fadda, C. and Dell'Acqua, M.(2017). Joining smallholder farmers' traditional knowledge with metric traits to select better varieties of Ethiopian wheat, nature scientific reports.

McGuire, S. (2005). Getting genes: rethinking seed system analysis and reform for sorghum in Ethiopia. $\mathrm{PhD}$ Thesis, Wageningen University, Wageningen. 
Mutegi, E. Signard F. Semagn, K. Deu, M. Muraya, M. Kanyenji, B. De Villiers, S. Kiambi, D. Herselman, L. Labuschagne, M. (2011). Genetic structure and relationship within and between cultivated and wild sorghum (Sorghum bicolor (L.) Moench) in Kenya as revealed by microsatellite markers. Theor Appl Genet 122:9891004

Nkongolo, K.K. Chinthu, K.K.L. Malusi, M., and Vokhiwa, Z. (2008) Participatory variety selection and characterization of Sorghum (Sorghum bicolor (L.) Moench) elite accessions from Malawian gene pool using farmer and breeder knowledge, African Journal of Agricultural Research , 3 :4, 273-283,

Ozturk, A. F. and Aydin, L.(2004). Effect of water stress at various growth stages on some quality characteristics of winter wheat. Journal of Agronomy and Crop Science, 190: 93-99.

Richard, R. A. and Jorgensen, R. S. ( 2008). Plant genetics and genomics: Crops and Models Springer Science Business Media, LLC, 233 Spring Street, New York, NY 10013, USA.

Romain, H. and Raemaekers, M. ( 2001). Crop production in tropical Africa. Directorate General for international Co-operation ministry of Foreign Affairs, External Trade and International Co-operation, Brussels, Belguum.

SDARC. (2015). Sekota Dryland Agricultura Reearch Center. Annual Progress Research Reports for the period 2006/07, 2007/08, 2008/09, 2009/10, 2012/13, 2013/14 and 2014/15. Sekota, Ethiopia

Subba Reddy, B.V. and Rao, N.G.P. (1971). Genetic analysis of some exotic Indian cross in sorghum varieties character association and response to selection in advance generation progenies. Indian Genetics, 31: 510520.

Yadav, S.K. Jyothilakshmi, N. Maheshwari, M. Vanja, M. and Venkateshwarlu, B. (2003). Influence of water deficit at anthesis and grain filling stages on water relation, osmotic adjustment and grain yield in sorghum. In: International Congress of Plant Physiology, New Delhi, Jan 8-12, 2003 , 222.

Yan, W. (2002). Singular value partitioning in biplot analysis of multienvironment trial data. Agronomy Jouranl, 94: $990-996$

Yan, W. and Kang, M.S. (2003). GGE Biplot Analysis: A Graphical Tool for Breeders, Geneticists and Agronomists. $1^{\text {st }}$ Edn., CRC Press LLC., Boca Roton, Florida, Pp: 271

Yan, W. (2001). GGE biplot a windows application for graphical analysis of multi-environment trial data and other types of two-way data. Agronomy Journal, 93:1111-1118 